\title{
COLDSPOT OF DECELERATED SEA-LEVEL RISE ON THE PACIFIC COAST OF NORTH AMERICA
}

\author{
Albert PARKer \\ School of Engineerig and Physical Science, James Cook University, Townsville, Australia
}

Manuscript received: February 9, 2016

Revised version: July 27, 2016

\begin{abstract}
PARKer, A., 2016. Cold-spots of Sea Level Intensifying Reduction along the West Coast of North America. Quaestiones Geographicae 35(3), Bogucki Wydawnictwo Naukowe, Poznań, pp. 31-37, 3 figs, 1 table.

ABSTRACT: We show here the presence of significant "coldspot" of sea level rise along the West Coast of the United States and Canada (including Alaska). The 30-years sea level for the area are mostly falling also at subsiding locations as San Francisco and Seattle where subsidence is responsible for a long term positive rate of rise. The 20 long term tide gauges of the area of length exceeding the 60 -years length have a naïve average rate of rise $-0.729 \mathrm{~mm} /$ year in the update 30 Apr-2015, down from $-0.624 \mathrm{~mm} /$ year in the update 14-Feb-2014. Therefore, along the West Coast of the United States and Canada the sea levels are on average falling, and becoming more and more negative.
\end{abstract}

KEY WORDS: sea level, measurements, tide gauges, West Coast of North America

Corresponding author: Albert Parker (e-mail: albertparker@y7mail.com)

\section{Introduction}

For the purpose of measuring the effects of climate change on sea level, the best basis is still the measure of the relative sea level by tide gauges, followed by the computation of relative rate of rise of sea level and the rate of change of this parameter. It is shown by using the latest surveys and data of the Permanent Service Mean Sea Levels (PSMSL) that the relative sea level is globally only oscillating about a small rising trend, without any positive acceleration. Some oscillations along the West Coast of the United States and Canada (including Alaska) are mostly negative, as some oscillations along the East Coast of the United States are mostly positive. This indicates the presence of significant "coldspot" of sea level rise along the West Coast of the United States and Canada (including Alaska) if we use the same logic of the "hotspot" claimed along the North Atlantic coast of the United States north of Cape Hatteras.

\section{The sea levels are increasingly decreasing along the West Coast of North America}

Sea levels have long been measured by tide gauges and tide gauge records of sufficient length permit the computation of reliable relative rates of rise or fall of sea levels (Parker et al. 2013, Parker 2014). The relative sea level at the tide gauge is largely variable from one location to another because of the different subsidence at the tide gauge, the different record length and the different phasing of the inter-annual and multi-decadal oscillations.

The Permanent Service on Mean Sea Levels PSMSL (PSMSL 2015) has released the latest 


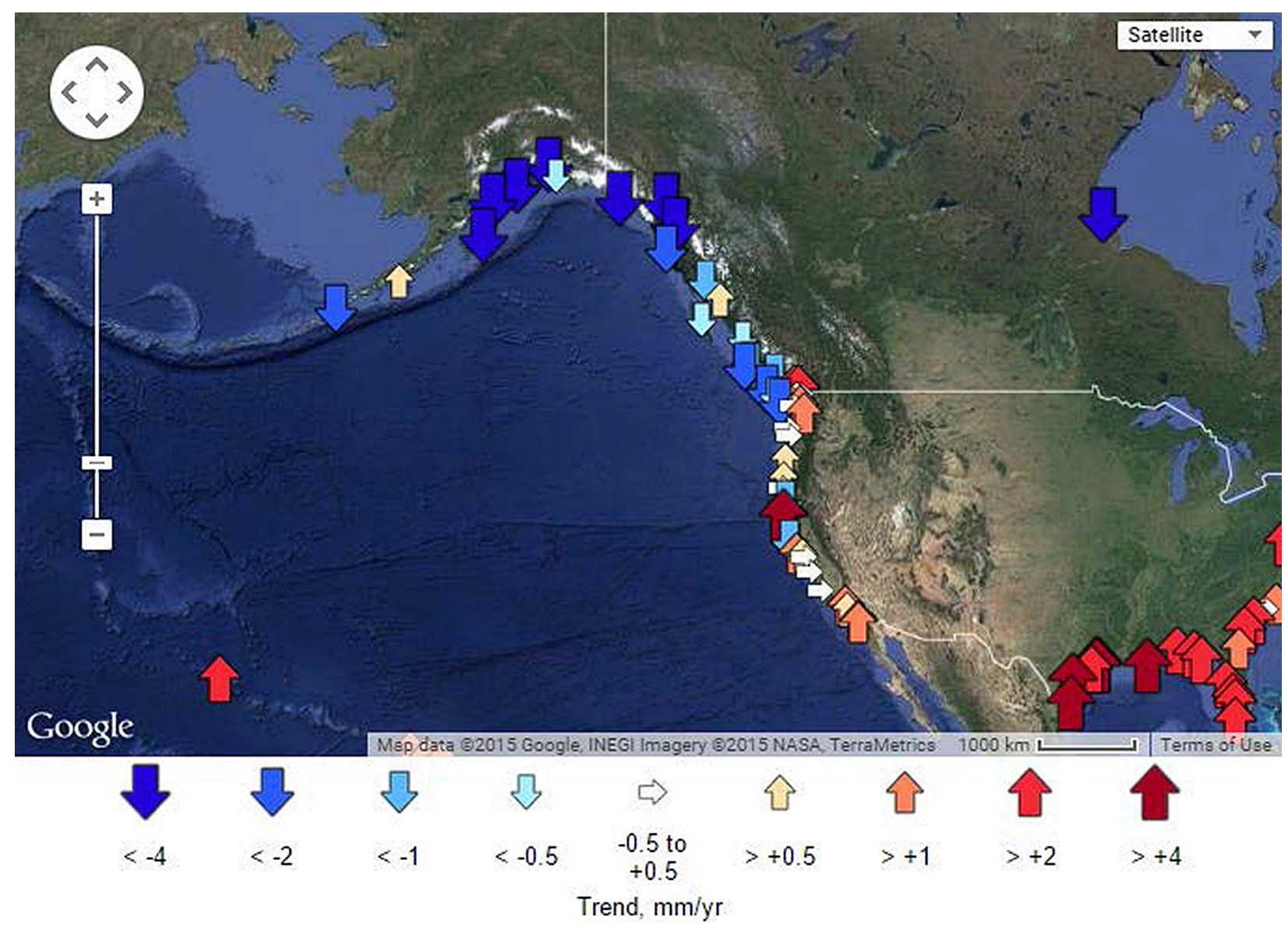

Fig. 1. Relative sea level rise trends over the time window 1984 to 2013 along the West Coast of the United States and Canada. Image taken from PSMSL (2015) with start year 1984 and end year 2013. If the east coast of the United States north of Cape Hatteras is characterised by seas rising at an increased rate to be called "hotspot" of positive acceleration, the West coast of the United States and Canada is characterised by seas falling at an increased rate and certainly similarly qualify as a "cold-spot" of deceleration or even more properly increasing falling rate.

survey of relative mean sea level from worldwide tide gauges. The analysis of the PSMSL surveys and data permits interesting conclusions to be drawn about the relative rate of rise by tide gauges. Most locations show a small relative rise without any sign of acceleration. For the analysis of the time series, the velocities are computed by linearly fitting the available data for the position.

The last update 30-Apr-2015 of the PSMSL survey proposes 571 tide gauges of maximum record length 188 years, minimum record length 27 years and average record length 60 years located in areas subject to differential subsidence or uplift resulting in a naïve averaged relative sea level rise of $+1.040 \mathrm{~mm} /$ year with maximum of $+10.250 \mathrm{~mm} /$ year and minimum of -17.660 $\mathrm{mm} /$ year. Similar numbers were computed in previous surveys, despite the random addition or removal of tide gauges located in areas of subsidence or uplift and having different record length.

As is well known , the climate indices oscillate with a quasi-60 years periodicity (Schlesinger, Ramankutty 1994) and the sea levels also oscillate worldwide with a quasi-60 years periodicity, of different amplitudes and phases from one tide gauge to the other (Chambers et al. 2012). Tide gauge records of length less than 60 years may overestimate or underestimate the relative rate of rise (Parker et al. 2013, Parker 2014). Considering only the tide gauges with 60 years of data, these 170 tide gauges have a naïve averaged relative sea level rise of $+0.248 \mathrm{~mm}$ /year with maximum of $+9.060 \mathrm{~mm} /$ year and minimum of $-13.250 \mathrm{~mm} /$ year. Differences between the 2014 and 2015 surveys are minimal, but if attention is paid to small differences, the change is negative, that is rates of rise are decreasing rather than increasing. The 
Table 1. Relative sea level velocities of the PSMSL tide gauges of the West Coast of the US including Alaska and Canada having more than 60 years of recorded data (updates 30-Apr-2015 and 14-Feb-2014). Data are from PSMSL (2015).

\begin{tabular}{|c|c|c|c|c|c|c|c|c|c|c|c|c|}
\hline & & & & & \multicolumn{8}{|c|}{ Relative sea level rate of rise [mm/year] } \\
\hline & & & & & \multicolumn{4}{|c|}{ Update 14-Feb-2014 } & \multicolumn{4}{|c|}{ Update 30-Apr-2015 } \\
\hline PSMSL & Latitude & Longitude & & $\begin{array}{l}\text { Station } \\
\text { name }\end{array}$ & $\begin{array}{l}\text { No. of } \\
\text { years } \\
\text { of data } \\
\text { used to } \\
\text { com- } \\
\text { pute the } \\
\text { trend }\end{array}$ & $\begin{array}{l}\text { Year } \\
\text { start }\end{array}$ & $\begin{array}{l}\text { Year } \\
\text { end }\end{array}$ & Trend & $\begin{array}{l}\text { No. of } \\
\text { years } \\
\text { of data } \\
\text { used to } \\
\text { com- } \\
\text { pute the } \\
\text { trend }\end{array}$ & $\begin{array}{l}\text { Year } \\
\text { start }\end{array}$ & $\begin{array}{l}\text { Year } \\
\text { end }\end{array}$ & Trend \\
\hline 158 & -32.713333 & 117.173333 & USA & $\begin{array}{c}\text { San Diego } \\
\text { (Quarantine } \\
\text { Station) }\end{array}$ & 104 & 1906 & 2012 & 2.06 & 108 & 1906 & 2013 & 2.04 \\
\hline 256 & -32.866667 & 117.256667 & USA & $\begin{array}{c}\text { La Jolla } \\
\text { (Scripps } \\
\text { Pier) }\end{array}$ & 80 & 1925 & 2012 & 2.07 & 86 & 1925 & 2013 & 2.04 \\
\hline 245 & -33.72 & 118.271667 & USA & Los Angeles & 87 & 1924 & 2012 & 0.85 & 90 & 1924 & 2013 & 0.83 \\
\hline 377 & -34.008333 & 118.5 & USA & $\begin{array}{c}\text { Santa Mon- } \\
\text { ica (Munici- } \\
\text { pal Pier) }\end{array}$ & 70 & 1933 & 2012 & 1.38 & 74 & 1933 & 2013 & 1.37 \\
\hline 508 & -35.176667 & 120.76 & USA & $\begin{array}{l}\text { Port San } \\
\text { Luis }\end{array}$ & 61 & 1946 & 2012 & 0.68 & 67 & 1946 & 2013 & 0.65 \\
\hline 437 & -37.771667 & 122.298333 & USA & $\begin{array}{c}\text { Alameda } \\
\text { (Naval Air } \\
\text { Station) }\end{array}$ & 71 & 1940 & 2012 & 0.64 & 74 & 1940 & 2013 & 0.55 \\
\hline 127 & -47.601667 & 122.338333 & USA & Seattle & 114 & 1899 & 2012 & 2.00 & 115 & 1899 & 2013 & 1.95 \\
\hline 10 & -37.806667 & 122.465 & USA & $\begin{array}{l}\text { San Fran- } \\
\text { cisco }\end{array}$ & 157 & 1855 & 2011 & 1.42 & 159 & 1855 & 2013 & 1.38 \\
\hline 384 & -48.546667 & 123.01 & USA & $\begin{array}{c}\text { Friday Har- } \\
\text { bor (Ocean. } \\
\text { Labs.) }\end{array}$ & 76 & 1934 & 2012 & 1.05 & 78 & 1934 & 2013 & 0.99 \\
\hline 193 & -49.333333 & 123.25 & CAN & $\begin{array}{c}\text { Point Atkin- } \\
\text { son }\end{array}$ & 71 & 1915 & 2012 & 0.85 & 79 & 1915 & 2013 & 0.92 \\
\hline 166 & -48.416667 & 123.366667 & CAN & Victoria & 101 & 1910 & 2012 & 0.63 & 104 & 1910 & 2013 & 0.59 \\
\hline 265 & -46.206667 & 123.768333 & USA & $\begin{array}{l}\text { Astoria } \\
\text { (Tongue } \\
\text { Point) }\end{array}$ & 86 & 1925 & 2012 & -0.28 & 89 & 1925 & 2013 & -0.35 \\
\hline 378 & -41.745 & 124.181667 & USA & $\begin{array}{l}\text { Crescent } \\
\text { City }\end{array}$ & 75 & 1933 & 2012 & -0.79 & 79 & 1933 & 2013 & -0.88 \\
\hline 385 & -48.366667 & 124.611667 & USA & Neah Bay & 74 & 1935 & 2012 & -1.7 & 79 & 1935 & 2013 & -1.84 \\
\hline 165 & -49.15 & 125.916667 & CAN & Tofino & 73 & 1910 & 2012 & -1.73 & 84 & 1910 & 2013 & -1.69 \\
\hline 167 & -54.316667 & 130.333333 & CAN & $\begin{array}{c}\text { Prince } \mathrm{Ru}- \\
\text { pert }\end{array}$ & 81 & 1909 & 2012 & 1.15 & 89 & 1909 & 2013 & 1.08 \\
\hline 225 & -55.331667 & 131.625 & USA & Ketchikan & 92 & 1919 & 2012 & -0.21 & 95 & 1919 & 2013 & -0.30 \\
\hline 405 & -58.298333 & 134.411667 & USA & Juneau & 74 & 1936 & 2012 & -13.08 & 75 & 1936 & 2013 & -13.25 \\
\hline 426 & -57.051667 & 135.341667 & USA & Sitka & 74 & 1938 & 2012 & -2.14 & 76 & 1938 & 2013 & -2.32 \\
\hline \multirow[t]{4}{*}{445} & -59.548333 & 139.733333 & USA & Yakutat & 69 & 1940 & 2012 & -7.33 & 74 & 1940 & 2013 & -8.34 \\
\hline & & & & & & & Max & 2.07 & & & Max & 2.04 \\
\hline & & & & & & & Min & -13.08 & & & Min & -13.25 \\
\hline & & & & & & & Ave & -0.624 & & & Ave & -0.729 \\
\hline
\end{tabular}



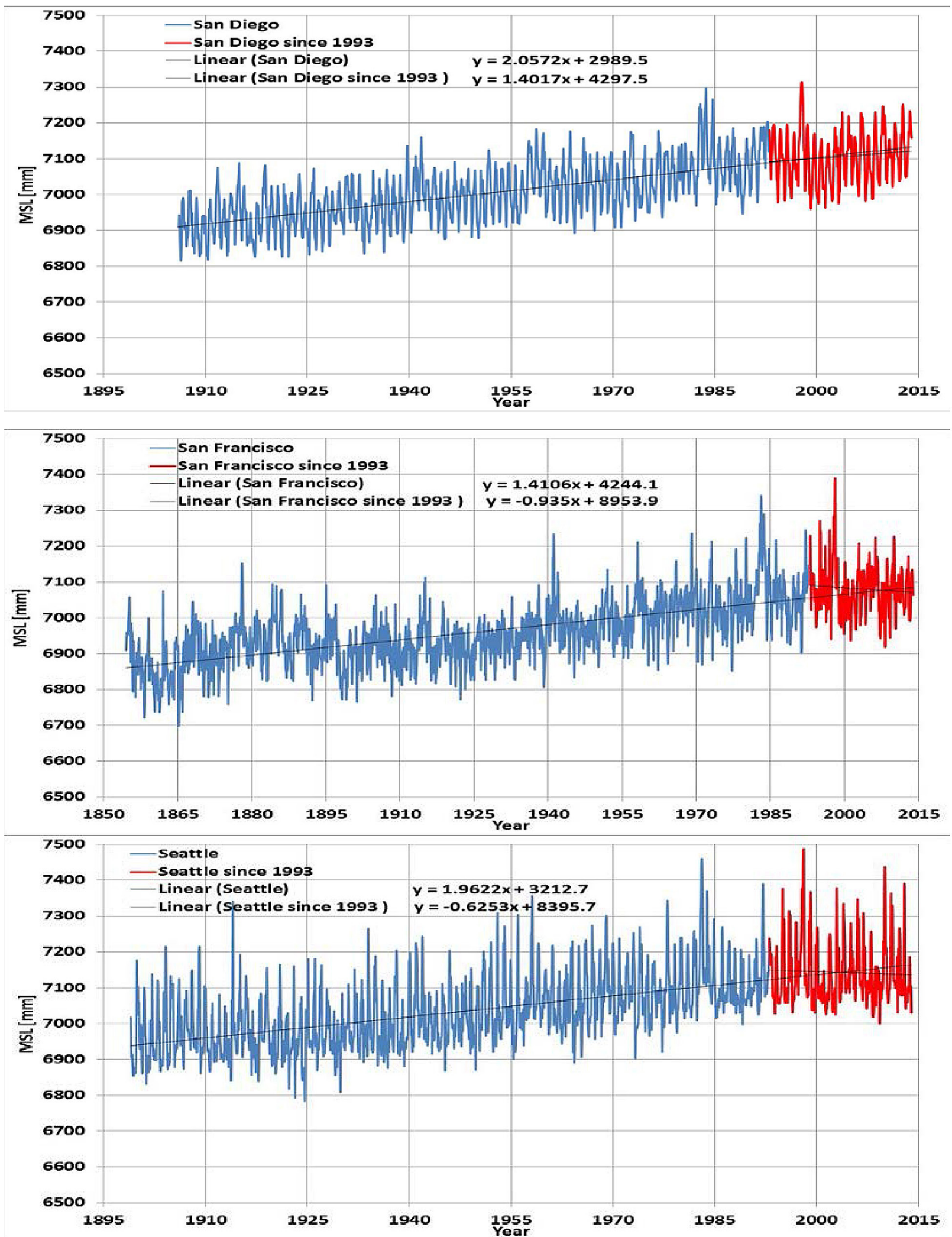

Fig. 2. Relative sea level velocity data in the locations of the US West Coast. Monthly average mean sea levels with the present relative rate of rise for San Diego (Quarantine Station) and San Francisco, CA and Seattle,

WA. Data from PSMSL (2015). The short time window for the rate of rise is the time span of the satellite reconstruction of the GMSL. Despite the long term subsidence, the short term relative rate of rise in Seattle and San Francisco are negative because of the multi-decadal oscillations. 


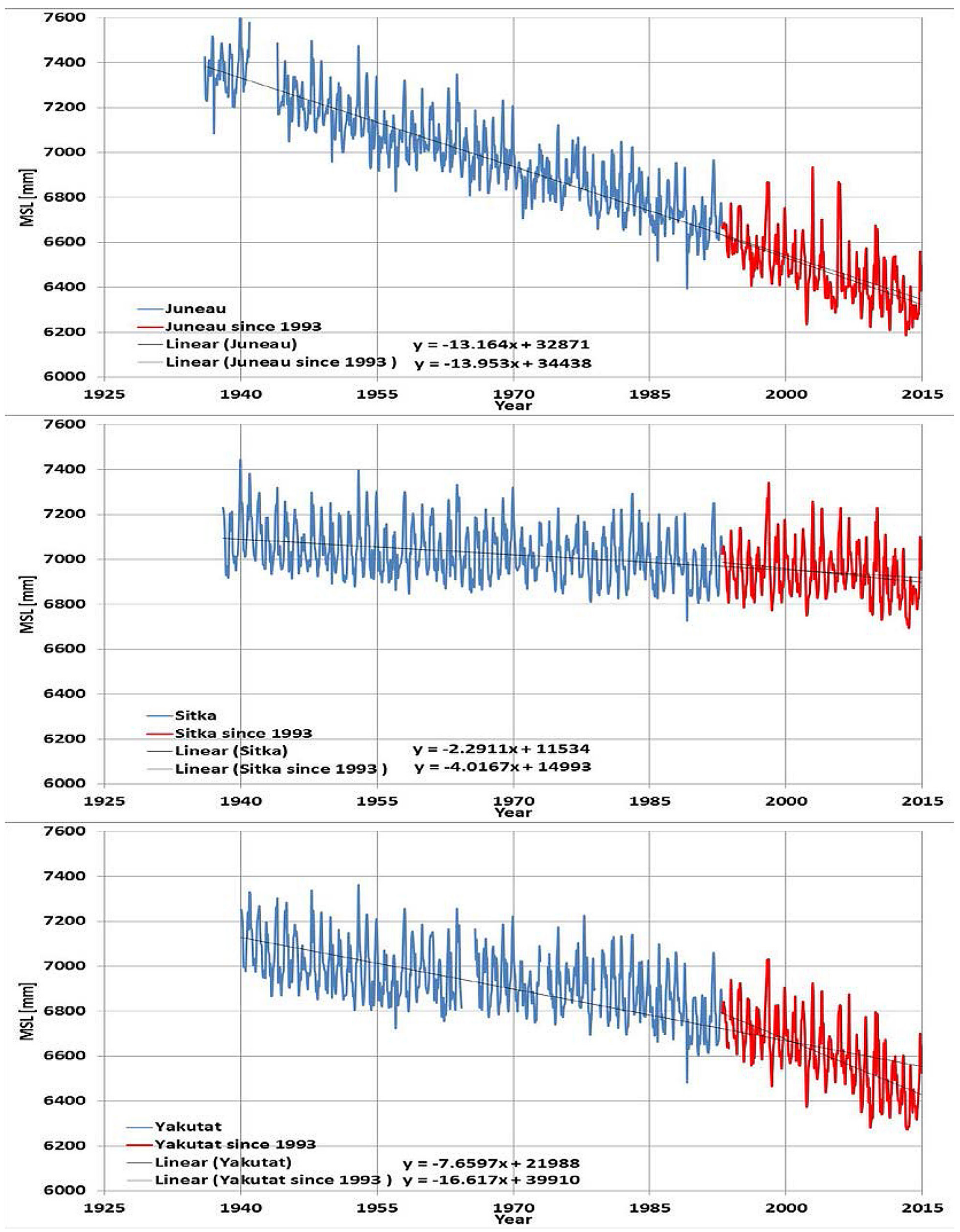

Fig. 3. Relative sea level velocity data in the locations of the US West Coast. Monthly average mean sea levels with the present relative rate of rise for Juneau, Sitka and Yakutat, AK. Data from PSMSL (2015). The short time window for the rate of rise is the time span of the satellite reconstruction of the GMSL. The sea level fall is intensified because of the multi-decadal oscillations. 
relative rates of rise at the individual tide gauges satisfying the minimum length requirements haven't changed from one update to the next over the last few decades. On average the relative rate of rise is small, and the relative rate of rise is not changing. However, if an area may be characterised to positive oscillations of sea levels as it is the North Atlantic coast of the United States north of Cape Hatteras (Sallenger et al. 2012), another area is characterised by negative oscillations of sea levels as it is the West Coast of the United States and Canada including Alaska.

Figure 1 presents the relative sea level map for the West coast of the United States and Canada from PSMSL (2015). The online facility only permits us to visualize the relative rates of rise computed with a 30 years' time window. All the tide gauges with data 1984 to 2013 in the PSMSL data base are listed. While the East coast certainly is a "hotspot" of positive acceleration, the West coast certainly qualifies as a "coldspot" of negative accelerations, as the relative sea level is mostly falling with increasing trend.

Table 1 is the survey of relative rates of rise PSMSL (2015) limited to the 20 tide gauges of length exceeding the 60 years of records along the west coast of the United States and Canada. The table presents the results proposed in the two latest surveys of 14-Feb-2014 and 30-Apr-2015. The 20 long term tide gauges of the area of length exceeding the 60-years length have a naïve average rate of rise $-0.729 \mathrm{~mm} /$ year in the update 30 -Apr2015 , down from $-0.624 \mathrm{~mm} /$ year in the update 14-Feb-2014. Therefore, along the West Coast of the United States and Canada the sea level is on average falling, that is becoming more negative.

Figures 2 and 3 present as an example the measured monthly average mean sea levels for San Francisco and San Diego, CA, Seattle, WA and Juneau, Sitka and Yakutat, AK on the West Coast of the United States. The linear fitting over the full time window suggest a relative rate of rise or fall of the sea levels that is linked to the sinking or uplift of the tide gauges. Since 1993, over the small time window of the satellite altimeter era, the tide gauges indicate much smaller relative rates of rise, or better much more negative relative rate of fall of sea levels. In the case of the CA and WA tide gauges, despite a subsidence rate very likely the long term relative sea level rise trend, the short term relative sea level rise trends are drastically reduced and in two of three cases negative. In the case of the three tide gauges of $\mathrm{AK}$, the rate of fall has further increased. This is only the effect of the multi-decadal and inter-annual oscillations, as noted for the "hotspot" along the North Atlantic coast of the United States north of Cape Hatteras (Parker 2013a,b). It is important to note as the sea levels worldwide are not rising everywhere, but rising or falling, and the accelerations are locally positive and negative to make globally zero acceleration showing great stability. A clear indication of this stability are the similar relative rates of rise of sea levels from one survey to the other, either the worldwide surveys by PSMSL (2015) or the United States surveys by the National Oceanic and Atmospheric Administration NOAA (NOAA 2015), with negligible differences however in the sign of reducing rates of rise as commented in Parker and Ollier (2015).

\section{Discussion and conclusions}

The sea level is not a straightforward indicator for climate change, as it depends on several concurrent causes. The tide gauge result is only a local indication of the oscillatory relative motion of the sea level vs. the instrument. Important control factors for local sea level changes measured tide gauges are the regional tectonic uplift or subsidence, and the local motions of the tide gauge instrument itself. Sea level changes are indeed an intriguing and intersecting item for tectonic investigations. Isostasy - regional as well as global - is another intriguing factor, which calls for multiple considerations and geophysical evaluations.

There are no "hotspots", nor "coldspots" of sea level rise, as the relative sea levels are not clearly accelerating, nor decelerating, but mostly oscillating. The best indication of the presence or absence of significant global warming is the acceleration in the relative sea level signals at the tide gauges, so far nowhere to be seen. Over the world, there are areas where the relative rates of rise are higher, and other areas where the relative rate of rise are smaller or even negative. Over the world, some of these rates are subject to small positive acceleration and some others are subject to small negative accelerations. The 
naïve averaging of the worldwide tide gauges of sufficient quality and length shows a small, rate of rise of sea level of $+0.24 \mathrm{~mm} /$ year acceleration free.

The stable low rising global mean sea levels are also confirmed by the satellite altimetry or the satellite gravimeter experiment when the relative result is not transformed in an absolute result by arbitrarily applying a global isostatic adjustment that is a local and not a global phenomenon (Mörner 2015).

As "hotspots" are always coupled to "coldspots" in globally neutral conditions such as those we are presently experiencing, it is shown that along the West Coast of the United States and Canada the 20 long term tide gauges with records over 60 -years have a naïve average rate of rise of the long term tide gauges $-0.729 \mathrm{~mm} /$ year in the update 30-Apr-2015, down from $-0.624 \mathrm{~mm} /$ year in the update 14-Feb-2014. All the tide gauges, regardless of record length, have mostly negative relative falling rates over the last 30 years also in areas of well-known subsidence.

Ocean and coastal management should not consider sea level rise scenarios only in the virtual reality of computer models, as policy makers should confront the observed fact that sea levels are rising by only a negligible amount with no acceleration worldwide, and falling more and more along the West Coast of the US and Canada, from San Diego, CA to Unalaska, AK.

\section{References}

Chambers D.P., Merrifield M.A., Nerem R.S., 2012. Is there a 60-year oscillation in global mean sea level? Geophysical Research Letters 39(17), art. no. L18607.

Mörner N.A., 2015. Glacial Isostasy: Regional - Not Global. International Journal of Geosciences 6: 577-592.

NOAA, 2015. Sea Level Trends U.S. Stations (tidesandcurrents. noaa.gov/sltrends/mslUSTrendsTable.htm; accessed: 1 July 2015).

Parker A., 2013a. Oscillations of sea level rise along the Atlantic coast of North America north of Cape Hatteras. Natural Hazards 65(1): 991-997.

Parker A., 2013b. Sea level trends at locations of the United States with more than 100 years of recording. Natural Hazards 65(1): 1011-1021.

Parker A., 2014. Minimum 60 years of recording are needed to compute the sea level rate of rise in the Western South Pacific. Nonlinear Engineering 3(1): 1-10.

Parker A., Ollier C., 2015. Discussion of A modelling study of coastal inundation induced by storm surge, sea-level rise, and subsidence in the Gulf of Mexico: the US average tide gauge is not accelerating consistently with the worldwide average. Physical Science International Journal 7(1): 49-54.

Parker A., Saad Saleem M., Lawson M., 2013. Sea-Level Trend Analysis for Coastal Management, Ocean and Coastal Management. Ocean \& Coastal Management 73: 63-81.

PSMSL, 2015. Relative Sea Level Trends (www.psmsl.org/ products/trends; accessed: 1 July 2015).

Sallenger A.H., Doran K.S., Howd P.A., 2012. Hotspot of accelerated sea-level rise on the Atlantic coast of North America. Nature Climate Change 2: 884-888.

Schlesinger M.E., Ramankutty N., 1994. An oscillation in the global climate system of period 65-70 years. Nature 367 (6465): 723-726. 